\title{
LITERASI INFORMASI MOTIVASI BERWIRAUSAHA IBU RUMAH TANGGA KELURAHAN NAGASARI KABUPATEN KARAWANG BARAT
}

\author{
Ute Lies Siti Khadijah $^{1}$, Diah Sri Rejeki ${ }^{2}$, Sukaesih $^{3}$, Rully Khairul Anwar ${ }^{4}$ \\ ${ }^{1,2,3,4}$ Program Studi Ilmu Perpustakaan Universitas Padjadjaran \\ ${ }^{1}$ ute.lies@unpad.ac.id, ${ }^{2}$ diahsr87@ gmail.com, \\ ${ }^{3}$ sukaesihcicih09@yahoo.com, ${ }^{4}$ rkha.fikom@gmail.com
}

ABSTRACT - Research on Information Literacy in fostering the motivation of entrepreneurial for the Housewife in the village of West Nagasari Karawang aims to find out the capabilities of literacy information entrepreneur owned the homemaker can cultivate entrepreneurship motivation to discuss economic families with housewife role as breadwinner. The research method used was qualitative with the design case studies. To collect the data is done by observation, in-depth interviews and literature study. The data source is the housewife, Literacy Expert Information, an expert on motivation, and references to Information Literacy and motivation. Based on the results of the research the housewives already has the capability of information literacy entrepreneurial conditioned, among other things: (1) being able to formulate information needs about entreprener, (2) is capable of updating the evaluation of the quality of the information, in this case the filter is capable of performing to the information will be used, (3) capable of storing and retrievel information, storage is done via media flash-disks and hard drive in the laptop, (4) are able to use information effectively and efficiently, the information obtained is used as a reference in the opening attempt and (5) able to communicate knowledge which can be with other parties, in this case the housewife doing sharing knowledge with her husband and other mothers already and have not experienced in the activities of the hero's efforts, (6) are capable of implementation information obtained about self-employment by opening a home business based on those results, are expected to help the other housewives in order to help improve the economy of their families.

Keywords: Information literacy, the entrepreneurial, motivation

ABSTRAK - Penelitian tentang Literasi Informasi Dalam Menumbuhkan Motivasi Berwirausaha Bagi Para Ibu Rumah Tangga di Kelurahan Nagasari Kabupaten Karawang Barat bertujuan untuk mengetahui kemampuan literasi informasi wirausaha yang dimiliki para ibu rumah tangga dapat menumbuhkan motivasi berwirausaha untuk memperbaiki ekonomi keluarga dengan peran ibu rumah tangga sebagai pencari nafkah tambahan. Metode penelitian yang digunakan adalah kualitatif dengan desain studi kasus. Pengumpulan data dilakukan dengan observasi, wawancara mendalam dan studi literatur. Sumber data nya adalah para ibu rumah tangga, pakar Literasi Informasi, Pakar Motivasi, dan referensi mengenai Literasi Informasi dan Motivasi. Berdasarkan hasil penelitian para ibu rumah tangga sudah memiliki kemampuan literasi informasi berwirausaha, antara lain: (1) mampu merumuskan kebutuhan informasi mengenai wirausaha, (2) mampu mengevaluasi kualitas informasi, dalam hal ini mampu melakukan filterisasi terhadap informasi yang akan digunakan, (3) mampu menyimpan dan menemukembalikan informasi, penyimpanan dilakukan melalui media flashdisk dan hardisk di laptop, (4) mampu menggunakan informasi secara efektif dan efisien,informasi yang didapat digunakan sebagai referensi dalam membuka usaha dan (5) mampu mengkomunikasikan pengetahuan yang didapat dengan pihak lain, dalam hal ini para ibu rumah tangga melakukan sharing knowledge dengan suaminya dan ibu-ibu lain yang sudah dan belum berpengalaman dalam kegiatan wirausaha, (6) mampu mengimplementasikan informasi yang didapat mengenai wirausaha dengan membuka bisnis rumahan berdasarkan hasil tersebut, diharapkan dapat membantu para ibu rumah tangga lainnya agar dapat membantu memperbaiki ekonomi keluarga mereka.

Kata kunci: Literasi informasi, wirausaha, motivasi

\section{PENDAHULUAN}

Anggapan bahwa seorang istri sebaiknya

mengurus suami dan anak, agar pekerjaan mencari nafkah menjadi tanggung jawab suami sudah 
menjadi hal yang umum di Indonesia. Namun, di zaman emansispasi seperti sekarang ini anggapan tersebut sudah tidak berlaku lagi.

Perempuan dan laki-laki mempunyai kesempatan yang sama dalam bekerja. Semua pekerjaan yang biasanya dilakukan oleh laki-laki, kini bisa juga dilakukan oleh perempuan, misalnya buruh pabrik, penjaga pom bensin, bahkan supir bus. Menurut hasil data riset yang dilakukan oleh media release jumlah pekerja wanita di Indonesia mencapai 54,44\% sedangkan wanita yang tidak bekerja sebanyak $45,56 \%$ (Media Release, 2016). Riset tersebut menunjukkan bahwa sebagian besar wanita di Indonesia sudah memahami pentingnya bekerja meskipun statusnya sebagai pencari nafkah tambahan.

Yang ingin saya soroti dalam penelitian ini adalah jumlah wanita yang tidak bekerja sebanyak 45,56\%. Meskipun jumlahnya lebih sedikit dari wanita bekerja, namun wanita yang tidak bekerja sedikit banyak akan mempengaruhi ekonomi keluarga.

Masalah ekonomi keluarga muncul karena ketidakmampuan dalam men- dapatkan penghasilan untuk memenuhi kebutuhan seharihari. Misalnya ketidakmampuan orangtua memberi makanan yang bergizi, pakaian yang bersih dan hunian yang nyaman bagi keluarganya, ketidakmampuan orang tua membiayai pendidikan ataupun kesehatan keluarganya, dan lain-lain. Dampak buruk bagi ketidakmampuan tersebut dapat berujung pada perceraian antara suami dan istri ataupun tindakan yang kriminal.

Bagi orang-orang yang tidak kuat iman, dia akan mudah terjerumus ke dalam tindakan yang tidak boleh dilakukan, misalnya karena tuntutan kebutuhan sehari-hari dan dia tidak mampu memenuhi kebutuhannya, maka jalan pintaslah yang akan diambil seperti mencuri, merampok, bahkan korupsi. Seperti yang dikemukakan oleh koran dalam Republika mengenai Fenomena Ibu-Ibu Mencuri dan Kemiskinan (Republika, 2016).

Dalam artikel tersebut dijelaskan bahwa fenomena ibu-ibu mencuri merupakan yang paling hangat saat ini, misalnya mengutil barang di mall, membobol rumah, mencongkel jendela, dan lainlain disebabkan oleh faktor ekonomi yang mendesak. Tingkat kejahatan yang semakin tinggi salah satunya dapat disebabkan oleh tekanan hidup dan tuntutan ekonomi dalam keluarganya. Namun, tidak semua orang memilih jalan pintas, banyak orang melakukan pekerjaan yang baik dan bekerja lebih giat untuk memenuhi semua kebutuhannya.

Salah satunya adalah seorang istri yang dapat berperan sebagai pencari nafkah tambahan dengan fungsi membantu suami dalam mencari nafkah. Mencari nafkah tambahan bagi seorang istri tidak harus pergi ke kantor setiap hari, bekerja di rumah pun bisa dilakukan. Misalnya, dengan membuka usaha yang diminati yaitu bisnis online, membuka warung makan, membuka warung kelontong, dan lain-lain.

Banyak kisah sukses seorang ibu rumah tangga yang melakukan bisnis dengan sedikit modal, seperti kisah inspiratif yang diceritakan oleh Marikxon dibawah ini: "Debbi Fields mengawali karirnya di dunia bisnis lewat hobinya sebagai ibu rumah tangga. Kebanyakan ibu rumah tangga memang jago memasak dan punya resepresep kreasi sendiri, termasuk Debbi Fields. Debbi menikah di usia 20 tahun setelah dropout dari perkuliahan dan tidak punya pengalaman bisnis 
apapun. Namun, Debbi punya kecintaan membuat kue sejak lama. Berawal dari pesta makan malam dimana Debbi dipermalukan karena salah menyebutkan kata "oriented" menjadi "orientated" ketika ditanya profesi Debbi oleh klien suaminya. Debbi mendirikan sebuah toko kue. Suaminya bahkan bertaruh Debbi tidak akan bisa menghasilkan \$50 dihari pertama dan memang benar, sama sekali tidak ada pembeli. Tidak menyerah Debbi membawa kue yang dia buat ke jalan dan mengijinkan orang-orang mencoba hingga dia menghasilka penjualan sebesar $\$ 75$. Namun, masih saja tokonya berjalan stagnan dan Debbi menyadari ada sesuatu yang harus diperbaiki. Debbi pun meng- atur target sales bukan hanya berdasarkan bulan tetapi bahkan perminggu dan sekarang perjam. Debbi Fields sukses dengan produk cookies buatannya yang populer di Amerika Serikat bernama "mrs. Fields". Sekarang Debbi Fields punya perusahaan bernilai kira- kira $\$ 450$ juta dari awalnya hanya sebuah bisnis rumahan".

Debbi Fields adalah salah satu contoh sukses seorang ibu rumah tangga yang membuka usaha melalui hobi yang disukainya. Melihat kondisi para ibu rumah tangga yang ada di Indonesia, mereka belum mempunyai keberanian untuk memulai dikarenakan berbagai alasan yaitu modal yang tidak ada, ketakutan akan sepi pembeli, ketakutan akan bangkrut, ketakutan akan tidak bisa membagi waktu antara keluarga dan pekerjaannya, dan lain-lain.

Kesimpulannya, motivasi para ibu rumah tangga dalam membuat usaha masih sangat kurang. Maka dari itu diperlukan suatu kemampuan literasi informasi mengenai wirausaha agar dapat menumbuhkan motivasi berwirausaha bagi para ibu rumah tangga.

Literasi informasi menurut American Library Association (ALA) is a set of abilities requiring individuals to recognize when information is needed and have the ability to locate, evaluate, and use effective needed information (ALA, 1989). Maksudnya, kemampuan individu untuk mengidentifikasi informasi yang dibutuhkan, kemampuan untuk mengakses dan menemukan informasi, kemampuan mengevaluasi informasi dan kemampuan menggunakan informasi tersebut secara efektif.

Kemampuan literasi informasi sangat dibutuhkan di era ledakan informasi seperti sekarang ini. Ledakan informasi ditandai dengan sulitnya mencari informasi yang tepat, sulitnya memilih informasi yang dibutuhkan dan sulitnya mendapatkan informasi yang sesuai dikarenakan informasi yang datang setiap detiknya sangat banyak dan tidak terbendung. Kemampuan literasi informasi yang dimiliki para ibu rumah tangga di kelurahan Nagasari Kabupaten Karawang Barat ini masih minim. Hal tersebut bisa dibuktikan dengan mudah percayanya mereka terhadap informasi yang masuk tanpa ditelaah lebih jauh mengenai akurasi sumbernya.

Mereka menelan mentah-mentah semua informasi yang masuk, tanpa melakukan filterisasi yang dampak negatifnya mereka jadi mudah dipengaruhi pihak lain. Namun, masih terdapat para ibu rumah tangga yang memiliki kemampuan literasi yang baik, yang bisa dibuktikan dengan para ibu rumah tangga yang membuka usaha di rumahnya berkat melakukan pencarian informasi di internet.

Berdasarkan penjelasan tersebut, tujuan penulis dalam melakukan penelitian ini adalah untuk mengetahui kemampuan literasi para ibu rumah tangga dalam menumbuhkan motivasi berwirausaha di Kelurahan Nagasari Kabupaten 
Karawang Barat. Harapannya, hasil dari penelitian ini bisa diimplementasikan bagi para ibu rumah tangga lain yang ingin ikut serta menjadi pencari nafkah tambahan untuk memperbaiki ekonomi keluarga mereka.

Maka rumusan masalah dalam penelitian ini adalah bagaimana kemampuan literasi informasi dalam menumbuhkan motivasi berwirausaha bagi para ibu rumah tangga di Kelurahan Nagasari Kabupaten Karawang Barat. Adapun kemampuan literasi informasi tersebut, penulis batasi menjadi kemampuan literasi informasi mengenai wirausaha.

\section{TINJAUAN PUSTAKA}

Pengertian literasi informasi secara umum adalah kemelekan informasi, yang artinya melek terhadap informasi. Menurut Dictionary for Library and Information Science oleh Eisenberg mendefinisikan literasi informasi:

"Information literacy is skill in finding the information one needs, including and understanding of how libraries are organized, fami- liarity with resource they provide (including information formats and automated search tools), and knowledge of commonly used techniques. The concept also includes the skills required to critically evaluate information content and employ it effectively, as well as understanding of the technological infrastructure on which information transmission is based, including its social, political, and cultural context and impact" (Eisenberg, 2004).

Berdasarkan definisi tersebut maka literasi informasi adalah kemampuan mencari informasi yang dibutuhkan, termasuk dalam memahami bagaimana cara mengelola perpustakaan, mengetahui istilah sumber daya yang di produksi termasuk format informasi dan alat pencarian informasi yang terautomasi serta mengetahui teknik-teknik yang biasa digunakan dalam pencarian informasi. Konsep tersebut juga termasuk dalam kemampuan mengevaluasi isi informasi dan menggunakannya secara efektif. Sama halnya dengan pendapat yang disampaikan America Library Association's Presidental Commite on Information Literacy berpendapat bahwa, "Information literacy is a set of abilities requiring individuals to recognize when information is needed and have the ability to locate, evaluate, and use effectivelly the needed information (ALA, 1989)".

Maksudnya adalah literasi informasi merupakan kemampuan individu dalam menentukan kapan informasi dibutuhkan dan mempunyai keahlian untuk menemukan, mengevaluasi dan menggunakannya secara efektif sesuai dengan kebutuhannya. Tujuan dari literasi informasi ini adalah memudahkan seseorang untuk belajar secara mandiri, memilah informasi yang akan digunakan ditengah era ledakan informasi, serta memenuhi kebutuhan informasinya baik untuk kebutuhan bersosialisasi, mencari pekerjaan, mencari informasi mengenai kesehatan ataupun informasi mengenai kehidupan dalam lingkungan bermasyarakat.

Tidak semua orang mempunyai kemampuan literasi informasi, ada beberapa persyaratan yang harus dimiliki oleh seorang literer informasi. Seperti yang dikatakan oleh Doyle dalam Wooliscroft kriteria literasi informasi yaitu: 
1. Menyadari kebutuhannya akan informasi. Seseorang tahu dan sadar akan informasi yang sedang dibutuhkannya

2. Menyadari informasi yang akurat dan lengkap merupakan dasar untuk membuat keputusan yang tepat. Informasi yang didapat bisa dijadikan acuan dalam menyelesaikan masalah ataupun membuat keputusan

3. Mengidentifikasi sumber-sumber potensial dari suatu informasi. Mampu menjabarkan maksud dan inti dari informasi yang didapat

4. Membangun strategi pencarian informasi yang tepat. Membuat strategi mengenai pencarian informasi yang akan dilakukan, misalnya pencarian dilakukan melalui internet dengan bantuan search engine

5. Mengakses sumber-sumber informasi Mampu mengakses informasi melalui media internet, televisi, surat kabar dan majalah

6. Mengevaluasi informasi. Mampu melakukan filter terhadap informasi yang dibutuhkan dan tidak dibutuh- kan.

7. Mengorganisasikan informasi untuk dipraktekan. Mengelola informasi yang didapat lalu diimplementasikan sesuai kebutuhan.

8. Mengintegrasikan informasi yang baru dengan yang sudah dimiliki sebelumnya. Menyatukan informasi yang baru dengan pengetahuan yang sudah ada agar tercipta pengetahuan yang baru.

Menggunakan informasi dengan kritis dan untuk menyelesaikan masalah. Informasi yang didapat, digunakan secara efektif dan efisien agar dapat dijadikan acuan sebagai penyelesaian masalah (Wooliscroft, 1997).
Hampir sama dengan yang dinyatakan oleh Campbell dalam Jesus bahwa terdapat elemenelemen dalam kemampuan literasi informasi, antara lain:

1. Merumuskan kebutuhan informasi. Kegunaan dari tahap ini adalah seseorang dapat mengetahui informasi yang benar-benar dibutuhkan dan akan dicari. Dalam hal ini, para ibu rumah tangga sudah mampu merumuskan kebutuhan informasi yang dicari, misalnya informasi mengenai bisnis rumahan, ide bisnis, peluang usaha, bisnis online, dan panduan berwirausaha lalu mereka mulai mencari informasi tersebut di internet, majalah, surat kabar ataupun televisi

2. Mengalokasikan dan mengevaluasi kualitas informasi. Mengalokasikan informasi dapat dilakukan dengan membuat daftar atau list agar dapat dengan mudah ditemukan kembali. Kualitas informasi dapat dilihat dari efektifitas penggunaan informasi tersebut dan kredibiltas dari sumber informasi. Para ibu rumah tangga sudah mampu menentukan kualitas informasi, hal ini bisa dibuktikan dengan informasi tersebut sesuai dengan logika, atau melihat narasumber dari informasi tersebut. Jika narasumbernya terkenal, maka mereka percaya akan kualitas informasinya

3. Menyimpan dan menemukembalikan informasi. Penyimpanan informasi dilakukan agar dapat memudahkan dalam melakukan temu balik informasi. Informasi yang dikumpulkan disimpan dalam flashdisk ataupun handphone agar dapat memudahkan dalam melakukan temu kembali informasi ketika dibutuhkan

4. Menggunakan informasi secara efektif dan efisien. Efektif dan efisien merupakan tepat 
sasaran dengan membutuhkan waktu yang cukup serta informasi yang dicari akurat. Informasi yang diperoleh dapat digunakan dengan efektif dan efisien, hal tersebut dapat dibuktikan dengan para ibu rumah tangga menggunakan informasi yang didapat sebagai dasar pengetahuan dalam mencari ide usaha, menganalisis peluang usaha dan membuka usaha

5. Mengkomunikasikan pengetahuan. Bisa diartikan seperti mencipatkan pengetahuan baru dan menyebarluaskan pengetahuan tersebut. Dalam tahap ini, para ibu rumah tangga sudah memiliki kemampuan untuk mengkomunikasikan kembali mengenai informasi yang diperoleh dengan orang lain yang membutuhkan informasi tersebut, misalnya sharing knowledege dengan tetangga ataupun suaminya sendiri (Jesus, 2006).

Kemampuan literasi informasi setiap orang berbeda tergantung dari frame of reference (kerangka pemikiran) dan field of experience (pengalaman) orang tersebut. Kemampuan literasi para ibu rumah tangga yang menjadi sampel dalam penelitian ini, bisa dikatakan cukup baik. Kemampuan literasi tersebut dapat menumbuhkan keinginan mereka untuk membantu suami dalam mencari nafkah tambahan, mengingat kondisi ekonomi yang sedang terpuruk. Keinginan tersebut bisa disamakan dengan motivasi.

Istilah motivasi bisa didefinisikan menjadi berbagai pengertian yakni harapan, dorongan, keinginan, kebutuhan, tujuan, sasaran, dan lainlain. Motivasi lahir dari kebutuhan manusia yang merasa ada kekurangan dalam hidupnya, misalnya ketika manusia merasa haus, maka dia akan membutuhkan air untuk mengisi rasa hausnya tersebut.
Begitu orang tersebut minum, maka kondisi kekurangan tersebut hilang, karena kebutuhannya sudah terpenuhi.

Sondang P. Siagian dalam buku Teori Motivasi dan Aplikasinya menjelaskan bahwa ada tiga komponen utama dalam motivasi, yaitu adanya kebutuhan, dorongan dan tujuan (Siagian, 2004). Kebutuhan timbul dari dalam diri seseorang yang merasakan ketidakseimbangan dalam hidupnya. Misalnya seseorang butuh sandang, papan dan pangan untuk memenuhi kebutuhan hidupnya.

Kebutuhan tersebut timbul secara naluriah dari dalam diri manusia. Motivasi yang kedua adalah dorongan, biasanya bersumber dari dalam diri seseorang namun bisa juga bersumber dari luar diri orang tersebut. Dorongan timbul ketika adanya usaha dari seseorang untuk mengatasi kondisi ketidakseimbangan tersebut. Misalnya ketika seseorang merasa lapar, maka dia akan berusaha mencari cara agar kondisi lapar tersebut hilang dengan cara makan. Motivasi yang terakhir adalah tujuan. Tujuan bisa diartikan sebagai sesuatu yang menghilangkan kebutuhan dan mengurangi dorongan, artinya jika tujuannnya tercapai maka kondisi ketidakseimbangan tidak akan terjadi.

Abraham H Maslow dalam Siagian menyatakan bahwa motivasi muncul karena adanya beberapa kebutuhan yang dimiliki manusia, antara lain:

1. Kebutuhan Fisiologis. Kebutuhan yang sifatnya menjaga keseimbangan hidup, misalnya sandang untuk berpakaian, papan untuk tempat istirahat, dan pangan untuk makan 
2. Kebutuhan akan keamanan. Kebutuhan akan rasa aman, misalnya bebas dari penyakit, bebas dari teror, bebas dari kekacauan, dan lainlain

3. Kebutuhan sosial. Manusia adalah mashluk sosial, manusia tidak dapat hidup tanpa bersosialisasi dengan manusia lainnya, maka sosial termasuk dalam salah satu kebutuhan dasar, misalnya kebutuhan memiliki keluarga, memiliki teman, memiliki cinta dari lawan jenis, dan lainlain.

4. Kebutuhan esteem. Manusia membutuhkan penghargaan atas segala sesuatu yang dilakukannya, misalnya kebutuhan dipuji, kebutuhan dihargai dan lain-lain

5. Kebutuhan untuk aktualisasi diri. Manusia membutuhkan dianggap "ada" oleh manusia lain, maka manusia mencari segala cara agar dapat terlihat kualitas dirinya, misalnya mencapai mimpi, berprestasi, dan lain-lain (Siagian, 2004).

Pada dasarnya Teori kebutuhan Maslow merupakan teori hierarki yang artinya jika satu kebutuhan sudah terpenuhi maka kebutuhan lainnya menanti. Jika manusia sudah merasa puas karena terpenuhi kebutuhannya, maka dia akan mencapai kesejahteraan hidup, namun apabila tidak terpenuhi kebutuhannya maka akan terjadi penyakit sosial, misalnya perceraian ataupun tindakan kriminal.

Dalam kasus ini penulis hanya mengambil teori kebutuhan fisiologis karena sesuai dengan hasil penelitian di lapangan bahwa faktor pemicu timbulnya motivasi berwirausaha para ibu rumah tangga adalah karena adanya tuntutan akan kebutuhan fisiologis.
Manusia membutuhkan makan dan minum untuk menghilangkan rasa lapar dan haus, manusia butuh tempat tinggal untuk menghindari panas terik dan hujan badai, serta manusia butuh pakaian yang bersih untuk menjaga kebersihan tubuhnya. Para ibu rumah tangga membutuhkan pendapatan tambahan karena sekarang yang mereka alami adalah pengeluaran lebih besar daripada pendapatan.

Kondisi dari beberapa para ibu rumah tangga yaitu ada yang memiliki suami pengangguran yang otomatis tidak ada pemasukan dan ada suami yang kerja hanya sebagai butuh pabrik dengan gaji dibawah UMK (Upah Minimum Kerja). Dengan kondisi tersebut, secara naluriah memotivasi para ibu rumah tangga untuk bekerja yang salah satunya dengan membuka usaha mandiri di rumah dengan keahlian dan kemampuan yang sudah mereka miliki. Salah satunya adalah kemampuan literasi informasi wirausaha.

\section{METODE PENELITIAN}

Penulis telah melakukan penelitian dengan menggunakan metode penelitian kualitatif deskriptif dengan desain studi kasus. Penelitian kualitatif dilakukan karena peneliti ingin mengeksplor fenomena-fenomena yang tidak dapat dikuantifikasikan yang bersifat deskrip- tif seperti proses suatu langkah kerja, formula suatu resep, pengertian-pengertian tentang suatu konsep yang beragam, karakteristik suatu barang atau jasa, gambar-gambar, gaya-gaya, tata cara suatu budaya, model fisik suatu artifak dan sebagainya (Satori, Djam'an: 
23). Metode ini melibatkan peneliti dalam melakukan observasi yang menyeluruh dan wawancara yang mendalam terhadap perilaku setiap individu dalam sampel penelitian.

Dalam hal ini penulis meneliti kemampuan literasi informasi wirausaha yang dimiliki para ibu rumah tangga dalam upaya menumbuhkan motivasi membuka usaha di rumahnya sebagai pembantu pencari nafkah tambahan untuk meningkatkan ekonomi keluarga yang baik.

Penelitian dilakukan di Perumahan Green Garden Kelurahan Nagasari Kabupaten Karawang Barat, objek dalam penelitian ini adalah literasi informasi dalam menumbuhkan motivasi berwirausaha sedangkan subjek penelitian ini adalah para ibu rumah tangga yang memiliki kondisi ekonomi buruk dan berhasil membuka usaha mandiri.

Dalam pemilihan informan, penulis menggunakan teknik Purposive Sampling yaitu ditentukan berdasarkan kriterian tertentu. Kriterianya adalah para ibu rumah tangga yang awalnya tidak mempunyai pekerjaan, namun sekarang bisa mandiri tanpa tergantung keuangan suami dengan membuka wirausaha sesuai bidang yang dimi- natinya.

Para ibu tersebut sebelumnya berada dalam kondisi ketidakseim- bangan ekonomi keluarga lalu mereka berusaha mencari cara untuk memenuhi kebutuhannya salah satunya dengan berwirausaha. Motivasi berwirausaha muncul ketika mereka melihat peng- alaman orang lain yang bisa mandiri bahkan sukses dengan membuka usaha dan melihat pengalaman sendiri betapa menderitanya hidup dalam kekurangan ekonomi serta didukung dengan kemampuan literasi informasi wirausaha yang mereka miliki.

Teknik pengumpulan data yang dilakukan yaitu observasi dan wawancara mendalam. Penulis melakukan observasi dan wawancara mendalam dengan datang ke rumah para ibu rumah tangga, dengan cara melihat dan mendengarkan lalu direkam tanpa sepengetahuan mereka agar mereka dapat menceritakannya secara natural dan tidak direkayasa.

\section{HASIL DAN PEMBAHASAN}

Kondisi ekonomi buruk dalam sebuah keluarga dapat memicu ter- jadinya perceraian bahkan tindakan kriminalitas. Kondisi ekonomi buruk adalah suatu kondisi dimana sebuah keluarga mempunyai pengeluaran yang lebih besar dari pendapatan sehingga terjadi ketidakseimbangan dalam bertahan hidup. Tuntutan biaya hidup yang semakin tinggi dengan ketidakmampuan keluarga dalam menangani kebutuhan fisiologislah yang memicu terjadinya perceraian dan tindakan kriminalitas tersebut. Untuk menghindari hal tersebut para ibu rumah tangga mempunyai keinginan untuk membantu meningkatkan ekonomi keluarga seba- gai pencari nafkah tambahan dengan membuka usaha di rumah masing-masing bermodalkan kemampuan literasi informasi yang dimiliki. Para ibu rumah tangga yang memiliki kriteria sebagai literer informasi wirausaha akan akan dijelaskan sebagai berikut.

Tabel 1. Kemampuan Literasi Informasi Wirausaha 


\begin{tabular}{|c|c|c|c|c|c|c|c|c|c|}
\hline $\begin{array}{l}\mathbf{N} \\
\mathbf{o}\end{array}$ & \begin{tabular}{|l|} 
Nama \\
Ibu \\
Ruma \\
h \\
Tang \\
ga \\
\end{tabular} & $\begin{array}{l}\text { Pekerjaa } \\
\text { n } \\
\text { Suami }\end{array}$ & $\begin{array}{l}\text { Kemampuan } \\
\text { Literasi } \\
\text { Wirausaha }\end{array}$ & $\begin{array}{l}\text { Wirausah } \\
\text { a Mandiri }\end{array}$ & & & & $\begin{array}{l}\text { 4. Mampu } \\
\text { mengkomunikasika } \\
\mathrm{n} \text { informasi dengan } \\
\text { cara } \\
\text { mendiskusikan } \\
\text { hasil penemuan }\end{array}$ & \\
\hline \multirow[t]{2}{*}{1.} & \multirow[t]{2}{*}{$\begin{array}{l}\text { Parti } \\
\text { (anak } \\
2 \text { ) }\end{array}$} & \multirow[t]{2}{*}{$\begin{array}{l}\text { Buruh } \\
\text { Pabrik }\end{array}$} & \multirow[b]{2}{*}{$\begin{array}{l}\text { 1. Mengetahui } \\
\text { informasi yang } \\
\text { dibutuhkan yaitu } \\
\text { mengenai ide } \\
\text { Usaha } \\
\text { 2. Mampu } \\
\text { mengumpulkan } \\
\text { berbagai sumber } \\
\text { informasi yang } \\
\text { dibutuhkan mulai } \\
\text { dari media surat } \\
\text { kabar, majalah, } \\
\text { televisi dan } \\
\text { internet. } \\
\text { 3. Mampu } \\
\text { menemukan } \\
\text { informasi di media } \\
\text { mengenai } \\
\text { wirausaha. } \\
\text { 4. Mampu } \\
\text { menentukan skala } \\
\text { prioritas dalam } \\
\text { penemuan } \\
\text { informasi. } \\
\text { 5. Mampu } \\
\text { mengkomunikasika } \\
\text { n informasi dengan } \\
\text { cara mendiskusikan } \\
\text { hasil penemuan } \\
\text { informasi kepada } \\
\text { suaminya. } \\
\text { 6. Mampu } \\
\text { menggunakan hasil } \\
\text { temuan informasi } \\
\text { sebagai dasar } \\
\text { membuka usaha. }\end{array}$} & \multirow[t]{2}{*}{$\begin{array}{l}\text { Warung } \\
\text { Bakso, } \\
\text { Mie } \\
\text { Ayam dan } \\
\text { Pecel Lele } \\
\text { di rumah }\end{array}$} & & & & $\begin{array}{l}\text { informasi kepada } \\
\text { suaminya. } \\
\text { 5. Mampu } \\
\text { menggunakan hasil } \\
\text { temuan informasi } \\
\text { sebagai dasar } \\
\text { membuka usaha }\end{array}$ & \\
\hline & & & & & \multirow[t]{2}{*}{3.} & \multirow[t]{2}{*}{$\begin{array}{l}\text { Lia } \\
\text { (belu } \\
\mathrm{m} \\
\text { punya } \\
\text { anak) }\end{array}$} & \multirow[t]{2}{*}{$\begin{array}{l}\text { Buruh } \\
\text { Pabrik }\end{array}$} & \multirow[t]{2}{*}{$\begin{array}{l}\text { 1. Mengetahui } \\
\text { informasi yang } \\
\text { dibutuhkan } \\
\text { mengenai panduan } \\
\text { wirausaha dan } \\
\text { peluang usaha. } \\
\text { 2. Mampu } \\
\text { mengumpulkan } \\
\text { sumber informasi } \\
\text { yang dibutuhkan } \\
\text { mulai dari sharing } \\
\text { knowledge dengan } \\
\text { tetangga yang } \\
\text { berpengalaman, } \\
\text { media internet dan } \\
\text { media majalah. } \\
\text { 3. Mampu } \\
\text { menemukan } \\
\text { informasi yang } \\
\text { dibutuhkan di } \\
\text { media internet. } \\
\text { 4. Mampu } \\
\text { mengkomunikasika } \\
\mathrm{n} \text { informasi dengan } \\
\text { cara } \\
\text { mendiskusikan } \\
\text { hasil penemuan } \\
\text { informasi kepada } \\
\text { suaminya. } \\
\text { 5. Mampu } \\
\text { menggunakan hasil } \\
\text { temuan }\end{array}$} & \multirow[t]{2}{*}{$\begin{array}{l}\text { Menjual } \\
\text { pernak } \\
\text { pernik } \\
\text { Hello } \\
\text { Kitty } \\
\text { (Warung } \\
\text { \& Online) }\end{array}$} \\
\hline \multirow[t]{2}{*}{2.} & \multirow{2}{*}{$\begin{array}{l}\text { Iyek } \\
\text { (belu } \\
\text { m } \\
\text { punya } \\
\text { anak) }\end{array}$} & \multirow[t]{2}{*}{$\begin{array}{l}\text { Tidak } \\
\text { Bekerja }\end{array}$} & \multirow[b]{2}{*}{$\begin{array}{l}\text { 1. Mengetahui } \\
\text { informasi yang } \\
\text { dibutuhkan } \\
\text { mengenai bisnis } \\
\text { online. } \\
\text { 2. Mampu } \\
\text { mengumpulkan } \\
\text { sumber informasi } \\
\text { yang dibutuhkan } \\
\text { mulai } \\
\text { dari sharing } \\
\text { knowledge dengan } \\
\text { tetangga yang } \\
\text { berpengalaman dan } \\
\text { media internet. } \\
\text { 3. Mampu } \\
\text { melakukan } \\
\text { filterisasi } \\
\text { terhadap informasi } \\
\text { yang ada di } \\
\text { internet. }\end{array}$} & \multirow[t]{2}{*}{$\begin{array}{l}\text { Menjual } \\
\text { Baju } \\
\text { Dewasa } \\
\text { (Online) }\end{array}$} & & & & & \\
\hline & & & & & 4. & $\begin{array}{l}\text { Dian } \\
\text { (belu } \\
\mathrm{m} \\
\text { punya } \\
\text { anak) }\end{array}$ & $\begin{array}{l}\text { Karyawa } \\
\text { n } \\
\text { Swasta }\end{array}$ & $\begin{array}{l}\text { 1. Mengetahui } \\
\text { informasi yang } \\
\text { dibutuhkan } \\
\text { mengenai bisnis } \\
\text { rumahan dan ide } \\
\text { bisnis. } \\
\text { 2. Mampu } \\
\text { mengumpulkan } \\
\text { sumber informasi } \\
\text { yang dibutuhkan } \\
\text { mulai dari media } \\
\text { televisi, media } \\
\text { majalah } \\
\text { dan media } \\
\text { internet. } \\
\text { 3. Mampu } \\
\text { menemukan }\end{array}$ & $\begin{array}{l}\text { Menjual } \\
\text { Baju } \\
\text { Muslim } \\
\text { (Toko \& } \\
\text { Online) }\end{array}$ \\
\hline
\end{tabular}




\begin{tabular}{|c|c|c|c|c|}
\hline & & & $\begin{array}{l}\text { informasi yang } \\
\text { dibutuhkan } \\
\text { melalui media } \\
\text { majalah. } \\
\text { 4. Mampu } \\
\text { mengkomunikasik } \\
\text { an informasi } \\
\text { dengan cara } \\
\text { mendiskusikan } \\
\text { hasil penemuan } \\
\text { informasi kepada } \\
\text { suaminya. } \\
\text { 5. Mampu } \\
\text { menggunakan } \\
\text { hasil temuan } \\
\text { informasi sebagai } \\
\text { dasar membuka } \\
\text { usaha. }\end{array}$ & \\
\hline 5. & $\begin{array}{l}\text { Ashri } \\
\text { (anak } \\
\text { satu) }\end{array}$ & $\begin{array}{l}\text { Tidak } \\
\text { Bekerja }\end{array}$ & $\begin{array}{l}\text { 1. Mampu } \\
\text { merumuskan } \\
\text { kebutuhan } \\
\text { informasi } \\
\text { mengenai bisnis } \\
\text { rumahan. } \\
\text { 2. Mampu } \\
\text { mengumpulkan } \\
\text { sumber informasi } \\
\text { yang dibutuhkan } \\
\text { mulai } \\
\text { dari sharing } \\
\text { knowledge dengan } \\
\text { tetangga yang } \\
\text { berpengalaman } \\
\text { dan media } \\
\text { internet. } \\
\text { 3. Mampu } \\
\text { mengkomunikasik } \\
\text { an } \\
\text { informasi dengan } \\
\text { cara } \\
\text { mendiskusikan } \\
\text { hasil penemuan } \\
\text { informasi kepada } \\
\text { suaminya. } \\
\text { 4. Mampu } \\
\text { menggunakan } \\
\text { hasil temuan } \\
\text { informasi sebagai } \\
\text { dasar membuka } \\
\text { usaha. }\end{array}$ & $\begin{array}{l}\text { Menjual } \\
\text { Makanan }\end{array}$ \\
\hline
\end{tabular}

Sumber: Analisis Lapangan

Berdasarkan hasil penelitian para ibu rumah tangga sudah memiliki kemampuan literasi informasi berwirausaha, antara lain: (1) mampu merumuskan kebutuhan informasi mengenai wirausaha, (2) mampu mengevaluasi kualitas informasi, dalam hal ini mampu melakukan filterisasi terhadap informasi yang akan digunakan, (3) mampu menyimpan dan menemukembalikan informasi, penyimpanan dilakukan melalui media flashdisk dan hardisk di laptop, (4) mampu menggunakan informasi secara efektif dan efisien, informasi yang didapat digunakan sebagai referensi dalam membuka usaha dan (5) mampu mengkomunikasikan pengetahuan yang didapat dengan pihak lain, dalam hal ini para ibu rumah tangga melakukan sharing knowledge dengan suaminya dan ibu-ibu lain yang sudah dan belum berpengalaman dalam kegiatan wirausaha. Literasi wirausaha yang dimiliki para ibu rumah tangga di dapat dari media televisi, media internet, media majalah, media surat kabar online serta sharing knowledge dengan para praktisi usahawan. Dengan modal memiliki kemampuan literasi informasi berwirausaha, maka timbul motivasi untuk mengimplementasikan informasi yang sudah didapat.

Salah satu bentuk implementasinya adalah dengan membuka usaha. Motivasi muncul karena adanya kebutuhan fisiologis para ibu rumah tangga. Para ibu tersebut sedang dalam keadaan ekonomi yang buruk, ada suami yang tidak bekerja ataupun suami bekerja dengan gaji kecil sedangkan tuntutan hidup semakin meningkat, misalnya Kebutuhan Hidup Layak seperti yang tertera dalam UU No.13 tahun 2003 tentang ketenagakerjaan, pemerintah menetapkan standar KHL sebagai dasar dalam penetapan upah minimum seperti yang diatur dalam pasal 88 ayat 4, adapun komponen yang termasuk dalam standar KHL antara lain makanan dan minuman, sandang, 
pe- rumahan, pendidikan, kesehatan, transportasi, rekreasi dan tabungan.

Untuk mencapai Kebutuhan hidup layak di Karawang sangatlah sulit, karena Karawang termasuk dalam kota yang memiliki biaya hidup yang tinggi. Melihat hal tersebut, maka para ibu rumah tangga membuka usaha di rumah sesuai dengan keahlian dan kemampuan yang dimiliki.

Berdasarkan hasil penelitian melalui observasi dan wawancara mendalam kepada para ibu rumah tangga di Perumahan Green Garden Kelurahan Nagasari Kabupaten Karawang Barat, mereka menjalani bisnis rumahan dengan modal kemampuan literasi berwirausaha yang baik karena termotivasi oleh ketidakseimbangan dalam kehidupan keluarga dari segi ekonomi.

Wirausaha yang dilakukan para ibu rumah tangga antara lain menjual pecel lele dan warung bakso di rumah, menjual pernak-pernik Hello Kitty secara online dan di rumah, menjual baju muslim secara online dan dirumah, menjual baju dewasa secara online dan di rumah, serta menjual makanan di rumah dan terkadang menitipkan dagangannya di warung-warung. Dalam kegiatan promosi yang mereka lakukan, mereka menggunakan media sosial facebook dan instagram sebagai media utama dalam mengiklankan produk mereka.

\section{SIMPULAN}

Sesuai paparan hasil dan pembahasan di atas, maka ditarik simpulan sebagai berikut:

1. Para ibu rumah tangga di perumahan Green Garden Kelurahan Nagasari Kecamatan Karawang Barat yang sudah memiliki kemampuan literasi informasi berwirausaha dalam menumbuhkan motivasi membuka usaha agar dapat dalam menumbuhkan motivasi membuka usaha agar dapat memperbaiki ekonomi keluarga yang buruk. 2. Para ibu rumah tangga tersebut sudah mampu merumuskan kebutuhan informasi yang dicari, misalnya informasi mengenai bisnis rumahan, ide bisnis, peluang usaha, bisnis online, dan panduan berwirausaha.

\section{DAFTAR PUSTAKA}

ALA. (1989). Retrieved Maret 2016, from Presidential Committee on Information Literacy: Final Report: http://www.ala.org/ala/mgrps/divs/a crl/ publications/whitepapers/presidenti al.cf m.

Media Release. (2016). Retrieved April 2016, from Jumlah Pekerja Wanita di Indonesia: http://www.media-release.info/juml ahpekerja-wanita-di-indonesia-544

Republika. (2016). Retrieved Mei 2016, from Fenomena Ibu-Ibu Mencuri dan Kemiskinan: http://m.republika.co.id/berita/kora n/opini-koran/16/01/09/o0ozwl1-fe nomena-ibuibu-mencuri-dan-kemis kinan

Eisenberg, M. B. (2004). Information Literacy: Essential Skills For The Information Age. London: Libraries Unlimited.

Jesus, L. (2006). Guidelines On Information Literacy For Lifelong Learning. Retrieved Maret 2016, from Veracruz: Information Literacy Section (infolit) of The International Federation of Library Association and Institutions (IFLA): http://www.ifla.org

Siagian, S. P. (2004). Teori Motivasi dan Aplikasinya. Jakarta: Rineka Cipta.

Wooliscroft, M. (1997). From Library User Education To Information Literacy: Some Issues Arising in This Evolutionary 
Process. COMLA Workshop . Bostwana:

COMLA Workshop . 